\title{
Morphology of gametes, post-fertilization events and the effect of temperature on the embryonic development of Astyanax altiparanae (Teleostei, Characidae)
}

\author{
Matheus Pereira dos Santos ${ }^{1}$, George Shigueki Yasui ${ }^{3}$, Pedro Luiz Porfírio Xavier ${ }^{4}$, \\ Nadya Soares de Macedo Adamov ${ }^{3}$, Nivaldo Ferreira do Nascimento ${ }^{2}$, Takafumi Fujimoto ${ }^{5}$, \\ José Augusto Senhorini $i^{3}$ and Laura Satiko Okada Nakaghi \\ Aquaculture Center, São Paulo State University, Jaboticabal, Brazil; National Center for Research and Conservation of \\ Continental Fish, Chico Mendes Institute of Biodiversity Conservation, Pirassununga, Brazil; Department of Veterinary \\ Medicine-FZEA, University of São Paulo, Pirassununga, Brazil; and Faculty of Fisheries Sciences, Hokkaido University, \\ Hakodate, Japan
}

Date submitted: 14.01.2016. Date revised: 15.03.2016. Date accepted: 24.03.2016

\section{Summary}

The aim of this study was to describe the morphology of gametes, post-fertilization events and subsequent temperature effects on the early developmental stages of the neotropical species Astyanax altiparanae. The sperm of this species presents a typical morphology of teleost sperm with a spherical head $($ diameter $=1.88 \mu \mathrm{m})$, midpiece (diameter $=0.75 \mu \mathrm{m})$ and a single flagellum (length $=18.67 \mu \mathrm{m}$ ). The extrusion of the second polar body and fusion of male and female pronucleus were reported for the first time in this species. Additionally, we observed the formation of the fertilization cone, which prevents polyspermic fertilization. Developmental stages at $22^{\circ} \mathrm{C}, 26^{\circ} \mathrm{C}$ and $30^{\circ} \mathrm{C}$ gave rise to fertilization rates at $91.12,91.42$ and $93.04 \%$ respectively. Hatching occurred at $25 \mathrm{hpf}$ at $22^{\circ} \mathrm{C}, 16 \mathrm{hpf}$ at $26^{\circ} \mathrm{C}$ and 11 hpf at $30^{\circ} \mathrm{C}$ and the hatching rates were $61.78 \%, 62.90 \%$ and $59.45 \%$, respectively. At $22^{\circ} \mathrm{C}$, the second polar body was extruded at $\approx 6 \mathrm{mpf}$ and the male and female pronucleus fused at $\approx 10 \mathrm{mpf}$. This fundamental information is important for the field and opens up new possibilities in fish biotechnology, including micromanipulation and chromosome-set manipulation.

Keywords: Embryo, Fish, Oocyte, Reproduction, Spermatozoa

\footnotetext{
${ }^{1}$ All correspondence to: Matheus Pereira dos Santos, Aquaculture Center, São Paulo State University, Via de Acesso Prof. Paulo Donato Castellane s/n, Jaboticabal, SP 14884-900, Brazil. E-mail: matheuspereira@ zootecnista.com.br

${ }^{2}$ Aquaculture Center, São Paulo State University, Via de Acesso Prof. Paulo Donato Castellane s/n, Jaboticabal, SP 14884-900, Brazil.

${ }^{3}$ Laboratory of Fish Biotechnology, National Center for Research and Conservation of Continental Fish, Chico Mendes Institute of Biodiversity Conservation, Rodovia Pref. Euberto Nemesio Pereira de Godoy, Pirassununga, SP 13630 970, Brazil.

${ }^{4}$ Department of Veterinary Medicine-FZEA, University of São Paulo, Avenida Duque de Caxias Norte 225, Pirassununga, SP 13630-080, Brazil.

${ }^{5}$ Faculty of Fisheries Sciences, Hokkaido University, 3-1-1 Minato-cho, 041-8611, Hakodate, Japan.
}

\section{Introduction}

The application of techniques involving genetics and reproduction in fish are important to improve aquaculture production. In recent years, several biotechniques including gamete and embryo manipulation have been developed for several fish species, these include germ-line chimera (Saito et al., 2008; Yasui et al., 2011), gynogenesis (Itono et al., 2007), chromosome manipulation (Komen \& Thorgaard, 2007; Piferrer et al., 2009) and transgenesis (Rembold et al., 2006). The application of these techniques includes the production of sterile fish (Peruzzi et al., 2009), monosex populations (Dunham, 1990) surrogate propagation (Yasui et al., 2011) and genetic improvement (Gjedrem, 2000; Arai, 2001). Although the potential of the biotechniques is mentioned above, the establishment 
of these techniques needs elucidation of some basic aspects of fish gametes, fertilization and developmental biology. The knowledge of post-fertilization events, such as the period of second polar body extrusion and pronucleus fusion are essential for their application, as this information allows the precise manipulation of embryology stages, where induction and manipulation of these techniques can be successfully applied.

The detailed gamete structures and developmental processes have been well studied previously in model fish species such as medaka (Iwamatsu, 2004) and zebrafish (Kimmel et al., 1995). The yellowtail tetra Astyanax altiparanae is a small characin species distributed in the neotropical region. This species is simple to breed, presents early sexual maturation, and shows high growth rates. Thus, this species is useful for both laboratory studies and aquaculture. Recently, we have established a protocol for gamete sampling, short-term storage and subsequent in vitro fertilization in this species (Yasui et al., 2015). Such work opened up new possibilities in the field of chromosome and embryo manipulation because we can control the fertilization timing by in vitro fertilization. However, for full application of other biotechniques it is necessary to study other parameters including gamete characteristics, mechanisms of fertilization and development.

Therefore, this paper aims to describe in detail the gamete morphology, post-fertilization events and the effect of three temperatures on the developmental stages for future application in reproductive biology in this species.

\section{Materials and methods}

All the procedures were performed in agreement with the Guide for the Care and Use of Laboratory Animals of University of São Paulo and the Ethics Committee for Animal Use at Centro Nacional de Pesquisa e Conservação da Biodiversidade Aquática Continental (CEUA/CEPTA \#02031.000033/2015-11).

\section{Origin of broodstock and fertilization}

In the following experiments, we used adult yellowtail tetra A. altiparanae. In order to establish a broodstock, fish were collected from the Mogi Guaçu river $\left(21.925706^{\circ} \mathrm{S}, 47.369496^{\circ} \mathrm{W}\right)$ and maintained in several earthen tanks of $1000 \mathrm{~m}^{2}$ at the Centro Nacional de Pesquisa e Conservação da Biodiversidade Aquática Continental/Instituto Chico Mendes de Conservação da Biodiversidade (CEPTA/ICMBio), in Pirassununga, Brazil. Fish were fed twice a day with a commercial pellet ( $1 \mathrm{~mm}$ diameter, $45 \%$ crude protein, $\left.3200 \mathrm{kcal} \mathrm{kg}^{-1}\right)$.
For in vitro fertilization, we used the procedures for gamete maturation, stripping and fertilization described in our previous protocol (Yasui et al., 2015). Males $(\approx 6 \mathrm{~cm})$ and females $(\approx 9 \mathrm{~cm})$ were anesthetized with menthol at $100 \mathrm{mg} \mathrm{L}^{-1}$ and then injected with OVOPEL ${ }^{\circledR}\left[\left(\mathrm{D}-\mathrm{Ala}^{6}, \mathrm{Pro}^{9}-\mathrm{NEt}\right)-\mathrm{mGnRH}\right.$ + metoclopramide] (3 $\mathrm{mg} \mathrm{kg}^{-1}$ for males and females). After injection, the fish were maintained in a $400-$ litre aquarium with the temperature set at $27^{\circ} \mathrm{C}$. When the spawning behaviour started (males follow the females through the aquarium), the fish were collected and anesthetized as mentioned above. Sperm was collected by stripping and using a $1000 \mu \mathrm{l}$ Eppendorf micropipette (Eppendorf, Germany). The collected sperm was immediately transferred to a 1.5 macrotube containing $400 \mu \mathrm{l}$ of modified Ringer's solution (128.3 $\mathrm{mM} \mathrm{NaCl}, 23.6 \mathrm{mM} \mathrm{KCl}, 3.6 \mathrm{mM} \mathrm{CaCl} 2,2.1 \mathrm{mM}$ $\mathrm{MgCl}_{2}$ ) and then maintained at $2.5^{\circ} \mathrm{C}$. Sperm quality was measured based on sperm motility (see Yasui et al., 2009 , 2012), and only samples presenting progressive motility above $80 \%$ were used for fertilization trials. Oocyte were sampled by stripping on a $100-\mathrm{mm}$ plastic Petri dish covered with a plastic film (Saran wrap). The egg mass from one female was inseminated with $100 \mu$ liluted sperm and activation was achieved by addition of $5 \mathrm{ml}$ distilled water. After $2 \mathrm{~min}$, the period of the sperm motility, the water volume was increased for incubation. Those procedures were performed in a room with the temperature set at $22^{\circ} \mathrm{C}$.

\section{Ultrastructure of gametes}

Females

Gametes from four mature females were analyzed. The samples were previously fixed in Karnovsky solution ( $2.5 \%$ glutaraldehyde $+2.5 \%$ paraformaldehyde) and post-fixed in osmium tetroxide at $1 \%$ for $2 \mathrm{~h}$, washed

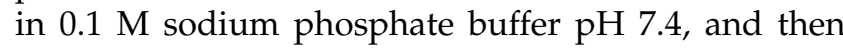
dehydrated in a graded series of ethanol. Then the samples were dried at the critical point in a liquid $\mathrm{CO}_{2}$ dryer, mounted onto stubs and coated in goldpalladium ions (Denton Vacuum, Desk II, LLC, Beijing, China), and subsequently scanned in a scanning electron microscope (Jeol - JSM 5410, Akishima, Tokyo, Japan).

\section{Males}

The following parameters were measured for each spermatozoa using Image $J^{\circledR}$ software: total length, in micrometres (TL) $(\mu \mathrm{m})$, head length (HL), head width (HW), length of the flagellum (LF) and length of the midpiece (LM). The results describing 30 spermatozoa were analyzed. 


\section{Histological observation of micropylar region}

Ten embryos were collected at $0,2,4,6,8,10,12,28$ and $30 \mathrm{~min}$ post-fertilization (mpf). The samples were incubated at $22^{\circ} \mathrm{C}$ and fixed in Karnovsky solution. The samples were then stored in $80 \%$ ethanol, and subsequently dehydrated, clearing and embedded in paraffin blocks, cut at a thickness of $2.5-5 \mu \mathrm{m}$, and stained with haematoxylin-eosin.

\section{Description of the second polar body}

For observation of the second polar body, six samples were taken at 2, 4, 6, 8, 10 or $12 \mathrm{mpf}$ in an incubation temperature of $22^{\circ} \mathrm{C}$, and then observed following the procedures described above for scanning electron microscopy processing.

\section{Observation of the pronucleus}

Embryos $(n=50)$ were examined under a fluorescence microscope. Fertilized eggs were sampled at 2-min intervals and fixed in 2\% glutaraldehyde in Dulbecco's phosphate-buffered saline (PBS) (Sigma \#D5773) until 30 mpf. For observation of the male and female pronucleus, the eggs were washed in $\mathrm{dPBS}$ and stained in a solution of 4,6-diamidino-2-fenilindone dihydrochloride (DAPI; SIGMA D9542) $1 \mu \mathrm{g} \mathrm{ml}^{-1}$ in $\mathrm{dPBS}$ for $10 \mathrm{~min}$. After staining, the eggs were placed on a microslide with apparatus to keep the position of the animal pole of the eggs and then observed under a microscope (Axioplan 2, ZEISS, USA), with fluorescence and filtering set to a wavelength of $254 \mathrm{~nm}$. Digital images were obtained using a charge coupled device (CCD) camera (MC 80 DX, ZEISS, USA) connected to the microscope using the Axion Vision 4 software (ZEISS, USA).

\section{Effect of temperature on development}

The fertilized eggs were divided into three aliquots and incubated at $22^{\circ} \mathrm{C}, 26^{\circ} \mathrm{C}$ or $30^{\circ} \mathrm{C}$. At 5 -min intervals, aliquots of $\approx 50$ eggs were fixed in $2.5 \%$ glutaraldehyde in Dulbecco's PBS. Samples were collected until the embryos reached 50 somites. Then, we described the developmental stages based on the observation of the fixed embryos by stereomicroscope (Nikon SMZ 1500, Nikon, Tokyo, Japan), equipped with a CCD camera (Nikon DS-Fi, Nikon, Japan). Digital images were taken using the software NisElements AR (Nikon, Tokyo, Japan). The criteria for classifying the developmental stages were the same as used by Fujimoto et al. (2006). We measured parameters such as fertilization rates (at the 2-cell stage), blastula, gastrula, somite, hatching, and the subsequent percentages of normal and abnormal larvae. In this experiment, we used four replicates, in which each replicate was obtained from different crosses. For each interval to be classified at a certain stage of development, 50 fixed and analyzed embryos (half or more than half) should present the same morphological characteristics.

\section{Statistical analysis}

Data are shown as mean \pm standard error. All analysis was obtained from triplicates, from different gamete sources. For evaluation of incubation temperature, we used four replicates. The percentages of embryo survival at each stage were compared at three temperatures of incubation and analyzed using SAS 9.0 software (SAS Institute, Cary, NC, USA). The percentages of cleavage, unfertilized eggs, blastula, gastrula, segmentation and hatching (with percentages of normal and abnormal larvae) were checked for normality by Lilliefors test and then analyzed by analysis of variance (ANOVA) and Tukey's multiple range test, with a significance level of $P<0.05$.

\section{Results}

\section{Ultrastructural analysis of gametes and post-fertilization events}

The Astyanax altiparanae sperm presented a total length of $21.22 \pm 4.29 \mu \mathrm{m}$, comprising head, midpiece and flagellum (Fig. 1A,B). The sperm head showed a spherical conformation with a diameter of $1.88 \pm$ $0.08 \mu \mathrm{m}$. The midpiece presented $0.75 \pm 0.19 \mu \mathrm{m}$ in length and a single flagellum with $18.67 \pm 4.32 \mu \mathrm{m}$. Among the hydrated oocytes, it is even possible to highlight the micropyle region, between the grooves (Fig. 1C). The micropylar channel could also be individualized and highlighted through histological sections (Fig. 1D). The non-hydrated oocytes showed spherical conformation with a diameter of $695.119 \pm$ $3.20 \mu \mathrm{m}$ considering the chorion. The chorion surface presented a single micropylar canal for fertilization surrounded by an extensive region containing several grooves (Fig. 1E). The micropyle was characterized as a small canal in the centre of grooves that helped to direct the sperm for fertilization. It was possible to observe the formation of the fertilization cone on the micropyle (Fig. 1F). In Astyanax altiparanae species, the fertilization cone showed different characteristics, comprising a rounded protuberance that covers the entire area of the micropyle, enveloping the exterior layer to the chorion. The yolk is concentrated in the vegetal pole and does not contain oil droplets, while the cytoplasmic area containing the nucleus was distributed over the animal pole with a translucent appearance. The perivitelline space was formed only after egg activation, corresponding to an 


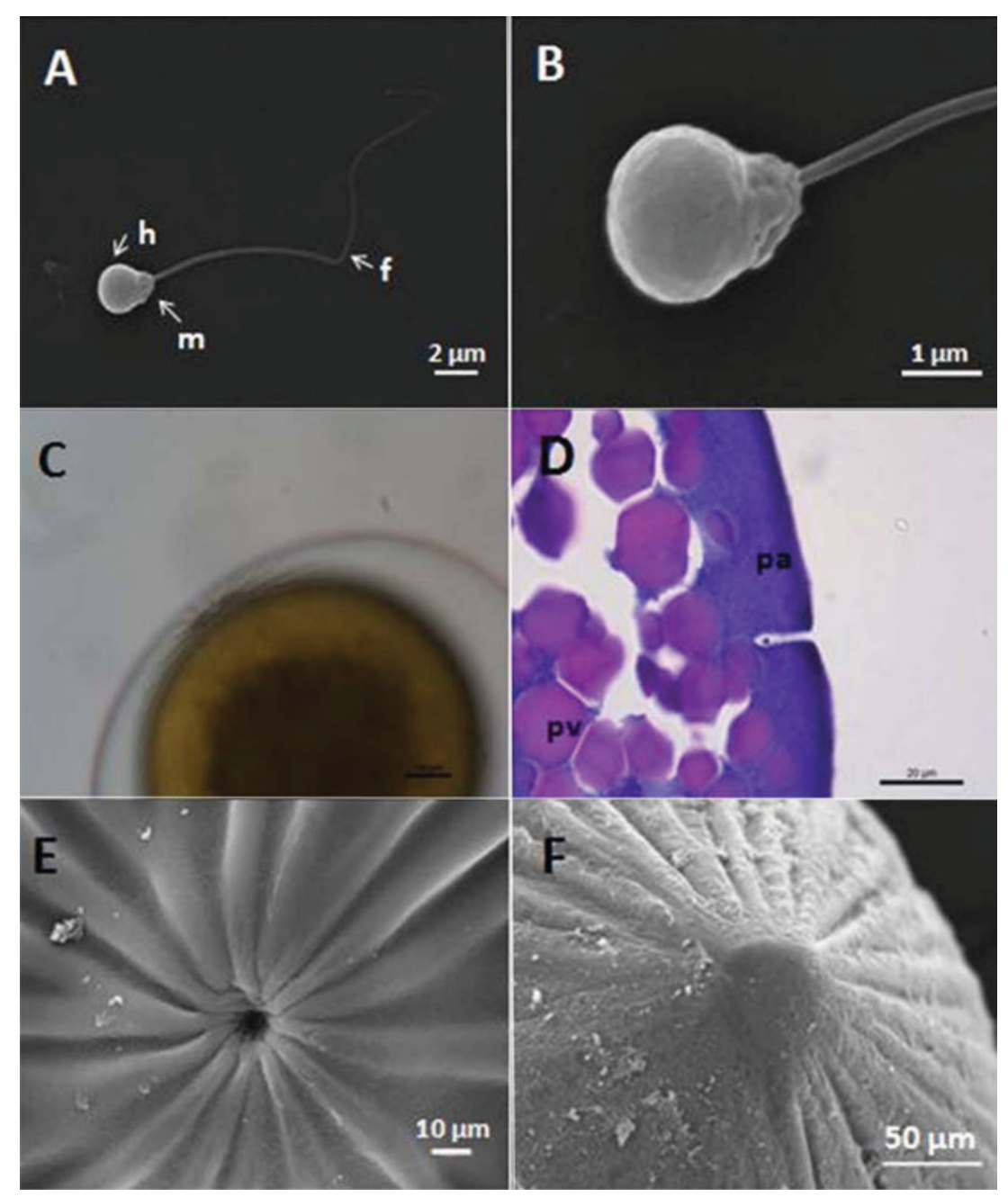

Figure 1 Overview of Astyanax altiparanae spermatozoa by SEM, showing the head (h), midpiece (m) and flagellum (f) $(A, B)$. In $(C)$ and $(D)$, photomicrographs of Astyanax altiparanae mature oocytes. Overview of the newly observed oocyte fertilized hydrated, with the perivitelline space $(C)$. Histological section of fertilized eggs, showing the micropylar channel in the animal pole region, moments before micropyle closure and formation of the fertilization cone; pa: animal pole, pv: vegetative pole $(D)$. In $(E)$ and $(F)$, the oocyte and egg of Astyanax altiparanae are shown. Micropyle and the grooves of the oocyte $(E)$. Newly fertilized egg and formation of the fertilization cone at $4 \mathrm{~min}$ after activation $(F)$. In this species, the cone closes the micropylar canal, extending to the chorion.

increase from 475 to $790 \mu \mathrm{m}$ in diameter. The newly fertilized eggs were spherical and were adhesive. Unhydrated oocytes were $695.119 \mu \mathrm{m}$ in diameter. After fertilization and subsequent hydration, the total diameter increased to $1170.909 \mu \mathrm{m}$.

Descriptive analyses performed in this study indicated the chronological events during fertilization in the species including the extrusion of the second polar body and fusion of the parental pronucleus which usually occur in diploid individuals and precede the onset of cell division and embryonic development. Extrusion of the second polar body occurred 4-6 min after fertilization as observed in our ultrastructural analysis using scanning electron microscopy (SEM)
(Fig. 2A, B). As observed in Fig. 2C, $D$, the egg nucleus was initially close to the micropylar area, where the entry of sperm, condensation and pronucleus fusion take place.

The condensed nucleus was positioned in the central region of the fertilized egg and began the cell division, giving rise to differentiation into the vegetative and animal poles. The fusion of the pronucleus, observed by fluorescence microscopy, occurred in a range $8-10$ min post-fertilization (mpf) (Fig. $2 C, D$ ) it was possible to observe the formation of the diploid nucleus of the embryo.

The percentages of unfertilized eggs at three temperatures are shown in Table 1 . In general, the 
Table 1 Percentages of the main qualitative stages of embryonic development in Astyanax altiparanae incubated at $22^{\circ} \mathrm{C}, 26^{\circ} \mathrm{C}$ or $30^{\circ} \mathrm{C}$

\begin{tabular}{llrrrrrrrr}
\hline & & \multicolumn{7}{c}{ Development stage (\%) } \\
\cline { 2 - 9 } Temperature & Value & Unfertilized & 2 cells & Blastula & Gastrula & Segmentation & Hatching & Normal & Abnormal \\
\hline $22^{\circ} \mathrm{C}$ & Average & 8.73 & 91.12 & 86.89 & 63.91 & 53.16 & 61.78 & 89.79 & 10.21 \\
& SD & 4.43 & 4.18 & 4.67 & 18.89 & 28.77 & 23.35 & 8.94 & 8.94 \\
$26^{\circ} \mathrm{C}$ & Average & 8.58 & 91.42 & 86.16 & 74.60 & 67.48 & 62.90 & 93.68 & 6.31 \\
& SD & 3.65 & 3.65 & 7.42 & 10.89 & 14.34 & 17.61 & 3.91 & 3.91 \\
$30^{\circ} \mathrm{C}$ & Average & 6.96 & 93.04 & 84.92 & 72.96 & 66.84 & 59.45 & 86.72 & 13.27 \\
& SD & 3.26 & 3.26 & 5.57 & 14.28 & 18.10 & 21.96 & 7.79 & 7.79 \\
\hline
\end{tabular}

Values that have no superscript letter indicate there was no significant difference between treatments $(P>0.05)$. $\mathrm{SD}$, standard deviation.

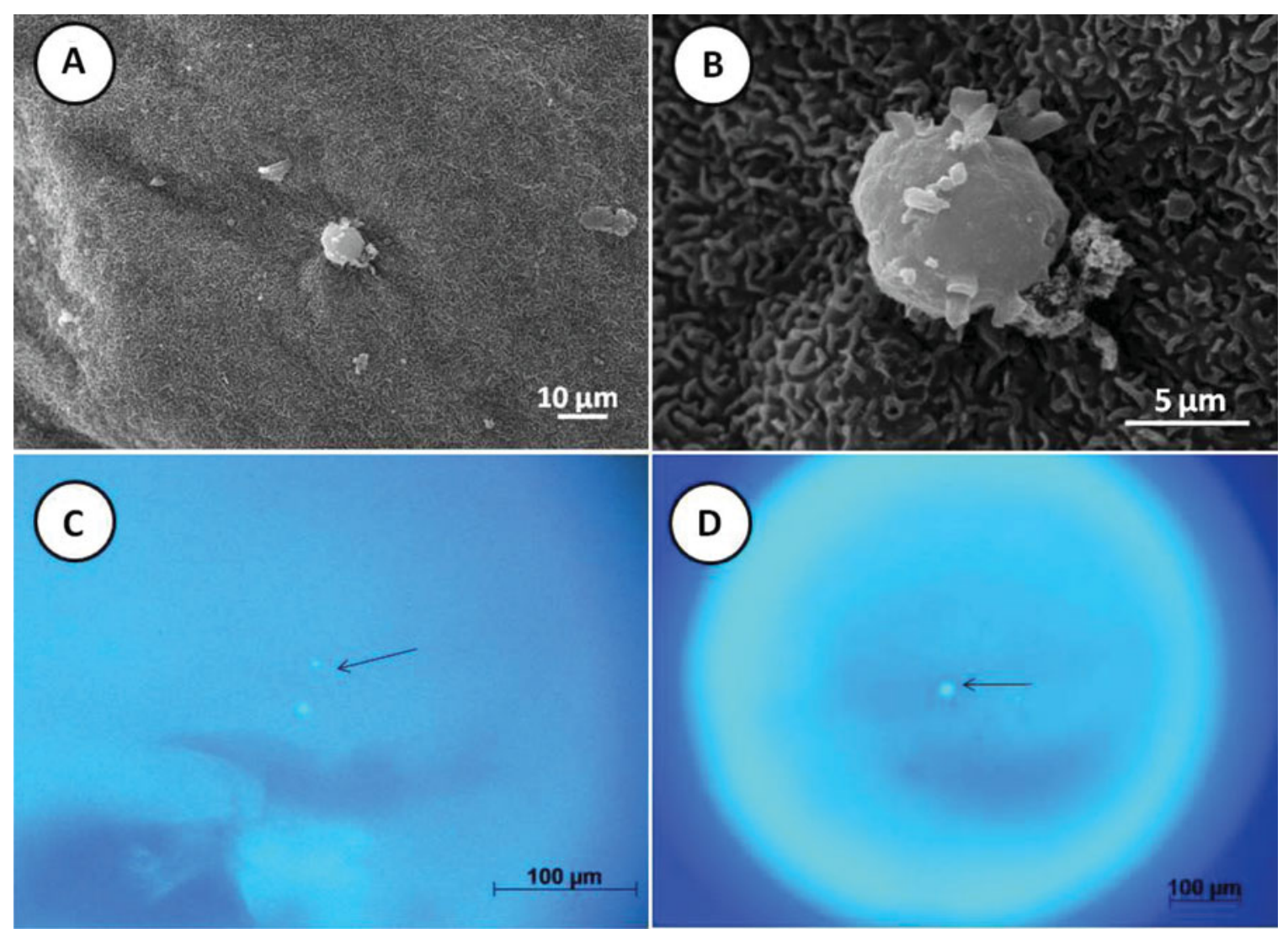

Figure 2 Scanning electron microscopy (SEM) of fertilized Astyanax altiparanae eggs and photomicrographs of newly fertilized eggs of Astyanax altipranae, stained with DAPI and observed by fluorescence. Egg with $6 \mathrm{mpf}$ general view $(A)$, it is possible to discriminate the second polar body, which was being extruded at 4-6 mpf. SEM of the eggs indicated a globular surface $(B)$. Overview of newly fertilized egg at $8 \mathrm{mpf}$, the embryo with pronucleus still individualized $(C)$. Prominent nucleus in the centre, in which the pronucleus fusion occurred at 8 to $10 \mathrm{mpf}(D)$. Arrows indicate the pronucleus after fusion.

survival percentage of embryos showed no significant differences at various developmental stages $(P>$ 0.05). However, one replicate at $22^{\circ} \mathrm{C}$ did not survive the segmentation stage. In this particular case, the percentage of embryos at the segmentation stage was only $18.28 \%$, which was $35 \%$ lower than the other three replicates for the same temperature.

\section{Embryo development of Astyanax altiparanae}

\section{Embryogenesis}

Developmental stages are presented in Table 2 that include the intervals of embryogenesis at three incubation temperatures.

Survival rates until hatching were $61.78,62.90$ and $59.45 \%$ at $22^{\circ} \mathrm{C}, 26^{\circ} \mathrm{C}$ and $30^{\circ} \mathrm{C}$, respectively 
Table 2 Range of embryonic development for Astyanax altiparanae incubated at temperatures of $22^{\circ} \mathrm{C}, 26^{\circ} \mathrm{C}$ and $30^{\circ} \mathrm{C}$

\begin{tabular}{|c|c|c|c|c|c|}
\hline \multirow[b]{2}{*}{ Stage } & & \multicolumn{3}{|c|}{ Time to stage } & \multirow[b]{2}{*}{ Figure no. } \\
\hline & & $22^{\circ} \mathrm{C}$ & $26^{\circ} \mathrm{C}$ & $30^{\circ} \mathrm{C}$ & \\
\hline \multirow[t]{6}{*}{ Cleavage } & $2-$ cell & $43 \mathrm{~min}$ & $28 \mathrm{~min}$ & $25 \mathrm{~min}$ & $3 B$ \\
\hline & 4-cell & $1 \mathrm{~h} 3 \mathrm{~min}$ & $40 \mathrm{~min}$ & $33 \mathrm{~min}$ & $3 C$ \\
\hline & 8-cell & $1 \mathrm{~h} 20 \mathrm{~min}$ & $53 \mathrm{~min}$ & $42 \mathrm{~min}$ & $3 \mathrm{D}$ \\
\hline & 16-cell & $1 \mathrm{~h} 33 \mathrm{~min}$ & $1 \mathrm{~h} 7 \mathrm{~min}$ & $52 \mathrm{~min}$ & $3 \mathrm{E}$ \\
\hline & 32-cell & $1 \mathrm{~h} 46 \mathrm{~min}$ & $1 \mathrm{~h} 18 \mathrm{~min}$ & $57 \mathrm{~min}$ & $3 F$ \\
\hline & 64-cell & $2 \mathrm{~h} 10 \mathrm{~min}$ & $1 \mathrm{~h} 23 \mathrm{~min}$ & $1 \mathrm{~h} 7 \mathrm{~min}$ & $3 G$ \\
\hline \multirow[t]{7}{*}{ Blastula } & 128-cell & $2 \mathrm{~h} 30 \mathrm{~min}$ & $1 \mathrm{~h} 26 \mathrm{~min}$ & $1 \mathrm{~h} 10 \mathrm{~min}$ & $3 \mathrm{H}$ \\
\hline & 256-cell & $2 \mathrm{~h} 40 \mathrm{~min}$ & $1 \mathrm{~h} 30 \mathrm{~min}$ & $1 \mathrm{~h} 13 \mathrm{~min}$ & $3 \mathrm{I}$ \\
\hline & 512-cell & $2 \mathrm{~h} 55 \mathrm{~min}$ & $1 \mathrm{~h} 40 \mathrm{~min}$ & $1 \mathrm{~h} 16 \mathrm{~min}$ & $3 \mathrm{~J}$ \\
\hline & 1000-cell & $3 \mathrm{~h} 15 \mathrm{~min}$ & $1 \mathrm{~h} 55 \mathrm{~min}$ & $1 \mathrm{~h} 25 \mathrm{~min}$ & $3 \mathrm{~K}$ \\
\hline & Elongation & $3 \mathrm{~h} 40 \mathrm{~min}$ & $2 \mathrm{~h} 10 \mathrm{~min}$ & $1 \mathrm{~h} 35 \mathrm{~min}$ & $3 \mathrm{~L}$ \\
\hline & Spherical & $4 \mathrm{~h} 10 \mathrm{~min}$ & $2 \mathrm{~h} 40 \mathrm{~min}$ & $1 \mathrm{~h} 55 \mathrm{~min}$ & $3 \mathrm{M}$ \\
\hline & Dome & $4 \mathrm{~h} 45 \mathrm{~min}$ & $3 \mathrm{~h} 10 \mathrm{~min}$ & $2 \mathrm{~h} 15 \mathrm{~min}$ & $3 \mathrm{~N}$ \\
\hline \multirow[t]{5}{*}{ Gastrula } & $25 \%$ epiboly & $5 \mathrm{~h} 10 \mathrm{~min}$ & $3 \mathrm{~h} 32 \mathrm{~min}$ & $2 \mathrm{~h} 43 \mathrm{~min}$ & 30 \\
\hline & $50 \%$ epiboly & $6 \mathrm{~h}$ & $3 \mathrm{~h} 53 \mathrm{~min}$ & $3 \mathrm{~h} 7 \mathrm{~min}$ & $3 P$ \\
\hline & Germ ring & $6 \mathrm{~h} 15 \mathrm{~min}$ & $4 \mathrm{~h}$ & $3 \mathrm{~h} 12 \mathrm{~min}$ & $3 Q$ \\
\hline & $70 \%$ epiboly & $6 \mathrm{~h} 45 \mathrm{~min}$ & $4 \mathrm{~h} 30 \mathrm{~min}$ & $3 \mathrm{~h} 27 \mathrm{~min}$ & $3 \hat{R}$ \\
\hline & $95 \%$ epiboly & $7 \mathrm{~h} 30 \mathrm{~min}$ & $5 \mathrm{~h} 20 \mathrm{~min}$ & $4 \mathrm{~h}$ & $3 S$ \\
\hline \multirow[t]{5}{*}{ Segmentation } & Neurula & $10 \mathrm{~h}$ & $6 \mathrm{~h} 17 \mathrm{~min}$ & $4 \mathrm{~h} 53 \mathrm{~min}$ & $4 \mathrm{~A}$ \\
\hline & Differentiating head and tail & 10h $45 \mathrm{~min}$ & $6 \mathrm{~h} 53 \mathrm{~min}$ & $5 \mathrm{~h} 3 \mathrm{~min}$ & $4 \mathrm{C}$ \\
\hline & Optic vesicle & $11 \mathrm{~h} 30 \mathrm{~min}$ & $7 \mathrm{~h} 20 \mathrm{~min}$ & $5 \mathrm{~h} 40 \mathrm{~min}$ & $4 \mathrm{E}$ \\
\hline & Kupffer's vesicle & $13 \mathrm{~h} 30 \mathrm{~min}$ & $8 \mathrm{~h} 33 \mathrm{~min}$ & $6 \mathrm{~h} 40 \mathrm{~min}$ & $4 \mathrm{H}$ \\
\hline & Region of yolk extension & $17 \mathrm{~h} 15 \mathrm{~min}$ & $10 \mathrm{~h} 43 \mathrm{~min}$ & $7 \mathrm{~h} 43 \mathrm{~min}$ & $4 \mathrm{M}$ \\
\hline \multirow[t]{2}{*}{ Hatching } & Kupffer's vesicle disappearance & $17 \mathrm{~h} 15 \mathrm{~min}$ & $10 \mathrm{~h} 47 \mathrm{~min}$ & $7 \mathrm{~h} 50 \mathrm{~min}$ & $4 \mathrm{O}$ \\
\hline & & $25 \mathrm{~h} 30 \mathrm{~min}$ & $16 \mathrm{~h} 10 \mathrm{~min}$ & $11 \mathrm{~h} 37 \mathrm{~min}$ & 5 \\
\hline
\end{tabular}

(Table 1). Samples incubated at $22^{\circ} \mathrm{C}$ presented lower survival rates at the cleavage stages $(91.12 \%)$, gastrula $(63.91 \%)$, segmentation $(53.16 \%)$ and hatching $(61.78 \%)$ when compared with the other two temperatures. Embryos maintained at $30^{\circ} \mathrm{C}$ had a higher percentage of abnormal hatched larvae $(13.27 \%)$. At $26^{\circ} \mathrm{C}$ more than $50 \%$ of the embryos survived all stages. After hydration of the eggs the perivitelline space arose and formed a visible animal pole, which is a translucent region of the egg.

\section{Cleavage period (2- to 64-cell stage)}

The cleavage stage marks the beginning of cell division, after the formation of the nucleus and subsequent blastodisc formation (Fig. 3A). As in other teleost species, the cleavage occurred in a partial meroblastic pattern exclusively at the animal pole. In addition, in each cell cleavage the cell diameter decreased substantially.

\section{2-cell stage}

This stage describes the first mitotic division of the embryo in a vertical plane, giving rise to two cells in the animal pole (Fig. 3B).

\section{4-cell stage}

The second cleavage was vertical and perpendicular to the first cleavage, giving rise to four blastomeres distributed in a $2 \times 2$ array on the yolk (Fig. 3C).

\section{8-cell stage}

This phase is formed by the third cell division, which is vertical to the previous division. At this time, the blastodisc comprises eight blastomeres formed by a $2 \times 4$ array (Fig. 3D).

\section{6-cell stage}

Sixteen blastomeres were originated in the fourth cell division (Fig. $3 E$ ) with arrangement in a $4 \times 4$ array, parallels the last cleavage embryo.

\section{2-cell stage}

The fifth cell division produces 32 blastomeres (Fig. 3F), irregularly monolayered and arranged in the central portion of the blastodisc ( $4 \times 8$ array), vertical and parallel to the first cleavage.

64-cell stage

The sixth embryonic cleavage followed a horizontal plane, giving rise to two layers of cells, a total of 64 


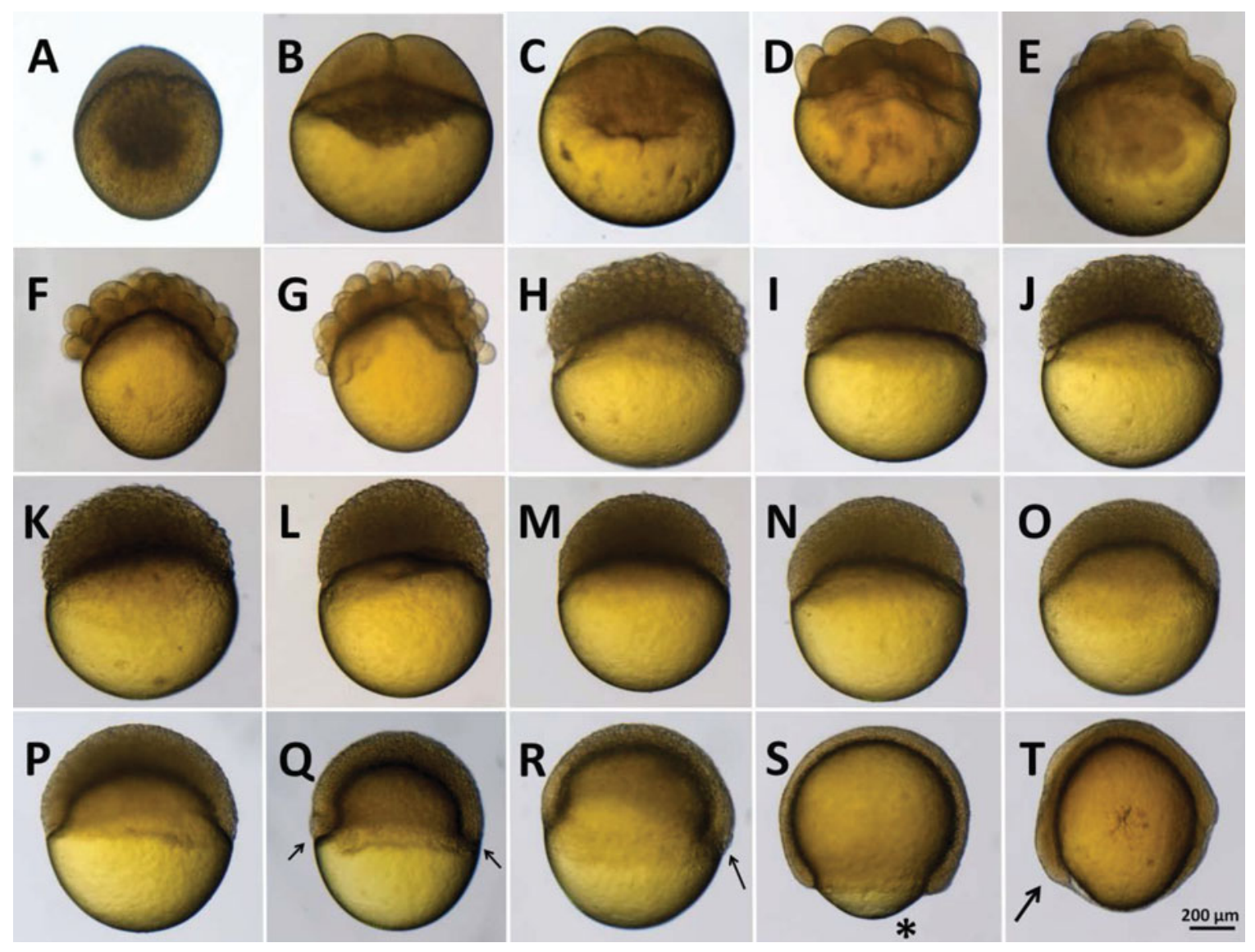

Figure 3 Early development of Astyanax altiparanae during the cleavage stages, blastula, gastrula and early segmentation, incubated at $26^{\circ} \mathrm{C}$. Differentiation of animal pole $(A) ; 2$-cell stage $(B) ; 4$-cell stage $(C) ; 8$-cell stage $(D)$; 16-cell stage $(E) ; 32$ cells stage $(F)$; 64-cell stage $(G)$; early blastula stage, with 128 blastomeres $(H)$; 256-blastomeres $(I)$; 512-blastomeres $(J), 1-\mathrm{K}$ blastomeres $(K)$; stretching $(L)$; sphere $(M)$; dome $(N)$; gastrula stage, $25 \%$ epiboly $(O)$; $50 \%$ epiboly $(P)$; germ ring (arrows indicate the germ ring) (Q); $70 \%$ of epiboly (arrow indicates the embryonic shield) ( $R$ ); $95 \%$ epiboly (asterisk indicates the local where occur the convergence movements) (S); initial segmentation, neurula stage (arrow indicates tail formation) (T).

blastomeres (Fig. 3G). During those divisions, there was a gradual increase in the number of blastomeres, with consequent gradual decrease in cell diameter.

\section{Blastula period (128- to 1024-cell stage)}

The blastula stage continue the cell cleavage and formation of the yolk syncytial layer (YSL ) or periblast.

The blastula was defined as early or late stages, according to some phases that characterize its progressive transitions. These phases are 128, 256, 512 and 1024 blastomeres according to the methodology described by Fujimoto et al. (2006). In the early stages of the blastula, there was an increase in the number of blastomeres resulting from synchronic cleavage divisions.

During this stage, the pattern of cell division was morphologically described through the stages specified below.

\section{8 blastomere stage}

In this stage an elevation of blastodisc is formed by multiple layers of cells originating from continuous cell divisions (Fig. $3 H$ ).

\section{6 and 512 blastomere stages}

In these stages, there was an asynchrony between cell divisions in the marginal and central blastodisc (Fig. 3I, J).

\section{1-K blastomere stage}

The tenth cleavage produces 1024 blastomeres (Fig. 3K).

\section{Elongation stage}

Embryos at this stage had an elliptical shape (Fig. $3 L$ ).

\section{Sphere stage}

The surface of the blastomeres presented a flatter appearance, giving the embryos a spherical shape, 
characteristic of this stage of the blastula stage (Fig. 3M).

\section{Dome stage}

The blastoderm assumes an aspect of the dome, and epiboly starts up to the initiation of the gastrula stage. At this stage, the embryos show about $30 \%$ epiboly movement (Fig. 3N).

\section{Gastrula period (50\% epiboly to blastopore closure)}

The gastrula stage was characterized by involution, convergence and extension of the embryos (Fig. 3O). The progressive epiboly movements gave rise to embryonic axis head-tail.

Morphogenetic movements of convergence and cell migration began at the border of the blastoderm, with about $50 \%$ of the epiboly movement, originating then in the germ ring and embryonic shield. Movements of epiboly continued with coverage of the yolk up to the complete closure of the yolk by the blastoderm.

\section{$50 \%$ epiboly stage}

Half of the yolk cell was covered with the blastoderm by the progress of epiboly movement (Fig. 3P).

\section{Germ ring phase and formation of the embryonic shield}

The germ ring was formed at the marginal part of the equatorial middle region of the yolk sphere. On the dorsal side, the embryonic shield was formed in part of the germ ring, and then epiboly movements restarted toward the vegetal pole (Fig. $3 Q, R$ ).

$70 \%$ epiboly stage

The blastoderm movement advanced and covered approximately $70 \%$ of yolk, with the yolk buffer region (Fig. 3S).

$100 \%$ epiboly stage

Movements of epiboly completely covered the marginal portion of the yolk, reaching $100 \%$ epiboly.

\section{Organogenesis period}

The organogenesis stage was divided into the neurulation, initial segmentation and late segmentation stages. In the course of organogenesis, there was a progressive increase in the number of somites.

Moreover, this stage was characterized by the formation of somites, rudimentary organs of the embryos.

\section{Initial segmentation-neurula}

At the neurulation stage (Figs $3 T$, and $4 A, B$ ), the separation of the caudal and cranial regions emerged and additionally the first somites arose (five to eight in the initial phase) (Fig. 4C), giving rise to the process of somitogenesis.

\section{5 somites stage}

A rudimentary optic vesicles was observed at this stage (Fig. 4D). Following this stage, about six to ten somites (Fig. 4E) differentiated into optic vesicles.

\section{2 to 18 somites stage}

During this phase, the optic vesicle was differentiated and visible (Fig. 4F, G). At the end of this period, it was also possible to identify the Kupffer's vesicle in more than half of the embryos. The number of somites increased to 12 somites, 15 somites (Fig. 4H), 17 somites (Fig. 4I), and 18 somites (Figs. 4J, K) and at these stages all embryos presented the tail attached to the yolk.

\section{0 to 30 somites stage}

At this point, the tail region was released from the yolk in all embryos (Fig. $4 L$ ), with a progressive increase in the number of somites (Fig. $4 M, N$ ). At 25 somites, the Kupffer's vesicle disappeared (Fig. 4O) and otic vesicles were formed (Fig. $4 P, Q$ ).

\section{0 somites stage}

This phase, known as 'delayed segmentation' represents the final stages prior to larvae hatching. In this period, we observed high asynchrony in groups collected at each interval, with variations in size, number of somites and developmental stages. The progressive consumption of the yolk was detected (Fig. 4R).

\section{Temperature effect on embryo development and hatching}

The three different incubation temperatures influenced mainly the incubation time until hatching. The main differences on development were observed during the period of organogenesis. The temperature of incubation influenced the survival percentages and at $22^{\circ} \mathrm{C}$, the embryo hatched with $\approx 60$ somites, although at $26^{\circ} \mathrm{C}$ and $30^{\circ} \mathrm{C}$, the embryo hatched with $\approx 50$ and $\approx 45$ somites.

Hatched larvae presenting free swimming and absence of malformations were classified as normal (Fig. 5). Various patterns of abnormalities were found including malformations in the tail, head, or even in size (Fig. $5 B, D, F$ ).

Increased temperatures accelerated the development of somites as shown in Fig. 6. However, some synchronies on the events were observed. At $22^{\circ} \mathrm{C}$, the Kupffer's vesicle arose with 15 somites, and at $26^{\circ} \mathrm{C}$ and $30^{\circ} \mathrm{C}$ it arose at 12 and 10 somites (Table 2). 


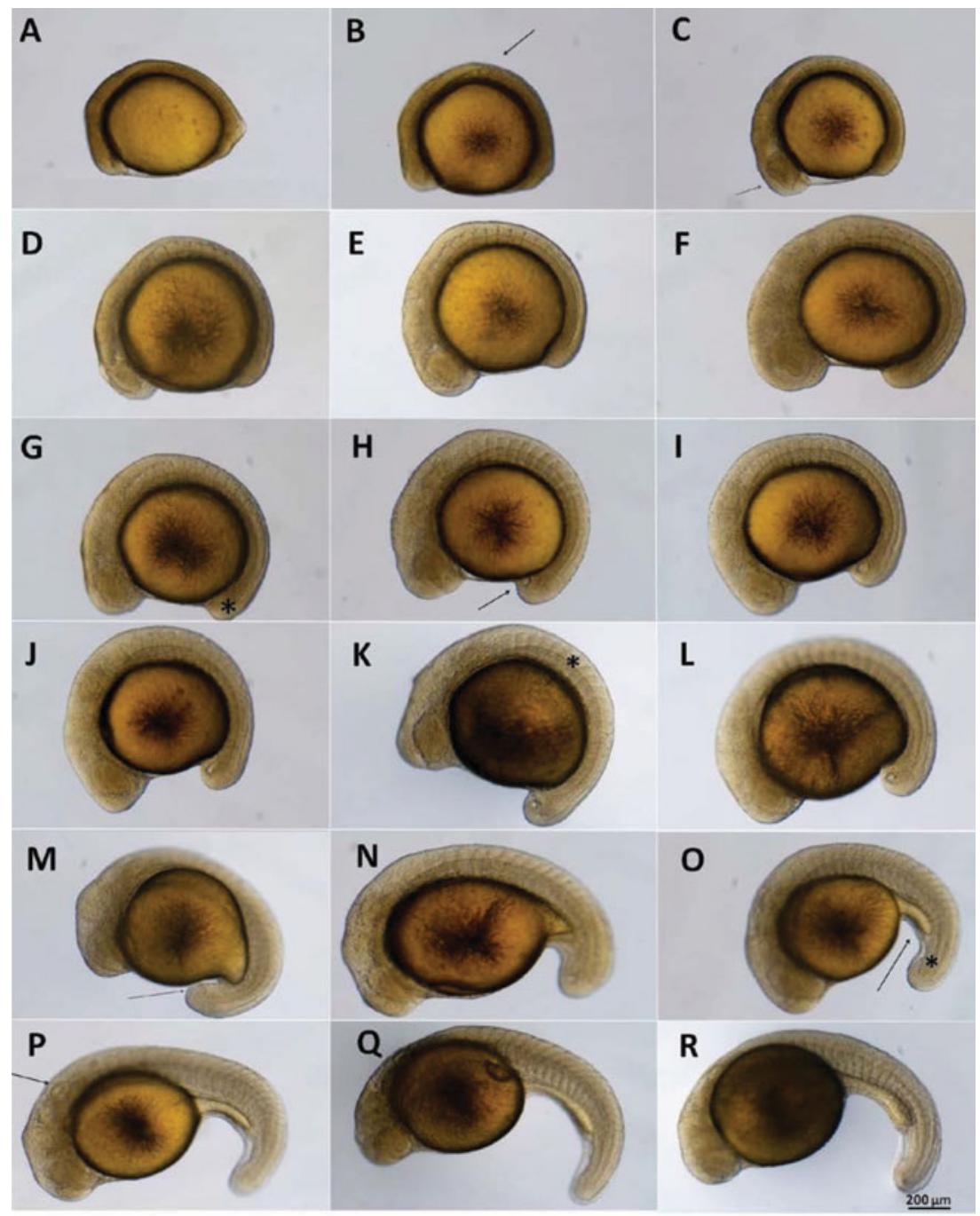

Figure 4 Astyanax altiparanae embryos during the early stages of segmentation, incubate at $26^{\circ} \mathrm{C}$. Early neurulation stage $(A)$; neurulation stage (arrow indicates the formation region of the first somites) $(B)$; 3-somite stage (arrow indicates the formation of the optic vesicle) $(C)$; 5 -somite stage $(D)$; 10-somite stage $(E)$; 12-somite stage $(F)$; 12-somite stage and tail formation (asterisk) $(G)$; 15-somite stage (arrow indicates the formation of the Kupffer's vesicle) $(H)$; 17-somite stage $(I)$; 18-somite stage $(J)$; 18somite stage, anterior and caudal regions is evident but the tail is still attached (asterisk indicates the location and distribution of the embryo somites) (K); 20-somite stage $(L)$; embryo with Kupffer's vesicle; (arrow indicates the start of loose of the caudal region) $(M)$; 22-somite stage $(N)$; embryo in 25-somite stage (arrow indicates the region of the yolk extension, asterisk indicates the disappearance of Kupffer's vesicle) $(O)$; embryo with 25 somites, highlighting the otic vesicle (arrow) $(P)$, embryo with 25 somites and the extension region of the well defined yolk $(Q)$, slightly curved embryo and contains ample yolk reserve, tail fully unfolded and about 27 somites $(R)$.

The hatching rates and the percentages of normal and abnormal larvae are shown in Table 1. Embryos incubated at $22^{\circ} \mathrm{C} \mathrm{h}$ at, approximately, $25 \mathrm{~h}$ and $30 \mathrm{~min}$; at $26^{\circ} \mathrm{C}, 16 \mathrm{~h}$ and $10 \mathrm{~min}$, and at $30^{\circ} \mathrm{C}$ the embryos hatched only aafter $11 \mathrm{~h} 37 \mathrm{~min}$ (Table 2).

Newly hatched larvae showed distinct patterns of length and height and yolk characteristics according to the incubation temperature. Embryos incubated at $22^{\circ} \mathrm{C}$ hatched with $2.313 \mathrm{~mm}$, to $26^{\circ} \mathrm{C}$ with $2.221 \mathrm{~mm}$ and $30^{\circ} \mathrm{C}$ with $1.924 \mathrm{~mm}$ in length. Thus, at higher temperatures the embryos hatched earlier, but with decreased length in relation to those incubated at lower temperatures.

\section{Discussion}

\section{Characterization of gametes and events post-fertilization}

The spermatozoa of the Astyanax altiparanae species presents with a spherical head, midpiece and a single flagellum, as already described for other teleosts 


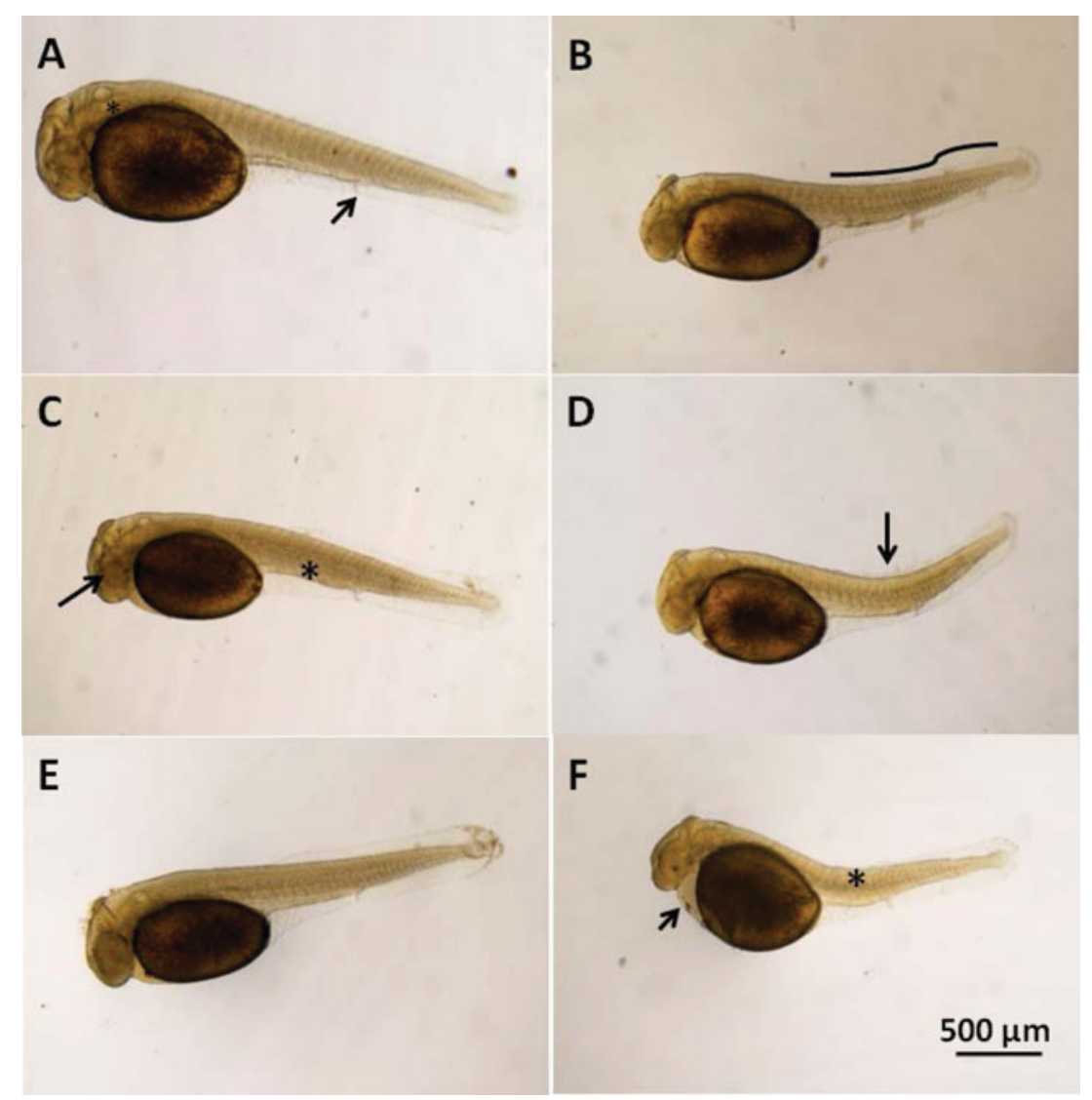

Figure 5 Astyanax altiparanae hatched larvae, demonstrating standards for normal and abnormal larvae. Newly hatched larva newly at $16 \mathrm{~h}-26^{\circ} \mathrm{C}$ with 55 somites (arrow indicates the formation of the anus, and the asterisk indicates the otic vesicle $(A)$. Larva containing abnormality in the caudal region $\left(17 \mathrm{~h} 30 \mathrm{~min}-26^{\circ} \mathrm{C}\right)(B)$. Normal larva (arrow indicates the well differentiated, optic vesicle and the asterisk indicates the region of the notochord $\left(17 \mathrm{~h} 30 \mathrm{~min}-26^{\circ} \mathrm{C}\right)(C)$. Hatched larva with abnormalities in the caudal region. The yolk shows a normal pattern, but the tail region presents abnormalities (arrow, $17 \mathrm{~h}$ $\left.-26^{\circ} \mathrm{C}\right)(D)$. Newly hatched larvae $\left(11 \mathrm{~h} 30 \mathrm{~min}-30^{\circ} \mathrm{C}\right)(E)$. Larvae from the same batch, with abnormalities in the tail region (asterisk) and yolk (arrow) $\left(11 \mathrm{~h} 20 \mathrm{~min}-30^{\circ} \mathrm{C}\right)(F)$.
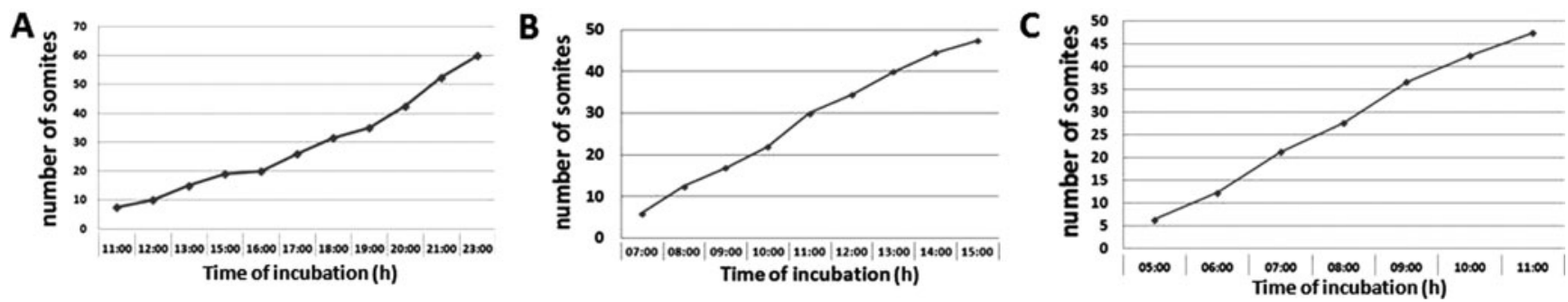

Figure 6 Increasing the number of somites along the embryonic development of Astyanax altiparanae incubated at a temperature at $22^{\circ} \mathrm{C}(A), 26^{\circ} \mathrm{C}(B)$ and $30^{\circ} \mathrm{C}(C)$.

including Carassius arautus (Fribourgh et al., 1970), Misgurnus anguillicaudatus (Ohta et al., 1993) and Colossoma macropomum (Maria et al., 2010). The LF is $18.67 \pm 4.32 \mu \mathrm{m}$, that is shorter than other characin species including Brycon cephalus (29.52 \pm $4.37 \mu \mathrm{m})$ and Colossoma macropomum $(29.84 \pm 1.63$ $\mu \mathrm{m})$ (Maria et al., 2010). According to the classification of Jamieson (1991) for teleosts, and Verissimo-Silveira et al. (2006) for Salminus maxillosus, the midpiece may be considered as small, according to its diameter $(0.75 \mu \mathrm{m})$. Regarding the diameter of the sperm head, the species has characteristics similar to those 
observed for other characins, such as Brycon nattereri (2.00 $\mu \mathrm{m}$; Viveiros et al., 2012), Brycon cephalus (1.72 $\mu \mathrm{m}$; Ninhaus-Silveira et al., 2006), Brycon siebenthalae (1.96 $\mu \mathrm{m}$; Cruz-Casallas et al., 2005) and Astyanax scabripinnis (1.8 $\mu \mathrm{m}$, Veloso-Júnior et al., 2009). The structure of the sperm also contributes to the success of fertilization, as characteristics such as size and conformation of the head are prerequisites for a successful penetration through the micropyle (Ginsburg, 1968).

The Astyanax altiparanae species showed high fertilization rates as observed in our previous studies which reported that gamete characteristics improved the fertilization ability (Yasui et al., 2015) including the grooves surrounding the micropyle that guides the spermatozoon to the fertilization area, a mechanism that is also found in sea urchins (Summers \& Hylander, 1975) and other teleosts (Amanze \& Iyengar, 1990; Hart, 1990). We also identified a mechanism for prevention of polyspermy that includes a fertilization cone that works as a physical barrier to other spermatozoa. Such a mechanism was also observed in other teleosts with external fertilization (Kudo, 1980). Soon after fertilization and the formation of the fertilization cone, the events that precede the first cleavage takes place.

The chronology of those events is essential to support other works in the field of genetics, reproduction and chromosome-set manipulation in fish. Induction of triploid individuals, tetraploid, gynogenetic and androgenesis involve techniques that affects the release of the second polar body and first cell cleavage (Komen \& Thorgaard, 2007; Piferrer et al., 2009).

Temperature affects the fertilization events and embryo development. Thus, we observed that lower temperatures at $22^{\circ} \mathrm{C}$ were adequate to incubate the eggs of yellowtail tetra that increased the time for manipulation of the second polar body, first cell cleavage and other developmental stages. Studies involving cell transplantation required a specific stage for collecting the cells from the donor and transplanting to the host embryos. Therefore, manipulation of water temperature may be used in the yellowtail to manipulate the period of cell transplantation.

The manipulation of the incubation temperature affected the percentages of abnormal embryos at the hatching stage, as reported in other neotropical teleosts (Rodrigues-Galdino et al., 2009). However, temperature resistance during incubation may be affected by the quality and quantity of yolk and the temperature raising the parental fish (Camus \& Koustikopoulos, 1984). It suggests that such a parameter may have influence in thermic tolerance and subsequent development in the yellowtail tetra. In the blastula, gastrula and especially segmentation stages, the influence of temperature was more evident.

The development pattern was the same as observed for other teleosts as described by Iwamatsu (2004) for Oryzias latipes, Fujimoto et al. (2006) for Misgurnus anguillicaudatus, Kimmel et al. (1995) for Danio rerio and Hall et al. (2004) for Gadus morhua.

Brooks \& Johnston (1994) reported that Paralichthys olivaceus incubated at $5^{\circ} \mathrm{C}$ had $9 \%$ more somites at the hatching stage compared with those incubated at $12^{\circ} \mathrm{C}$. Incubation temperature also affected the embryo staging at hatching in the yellowtail tetra, in which a decreased number of somites was found at $30^{\circ} \mathrm{C}$ compared with those incubated at $22^{\circ} \mathrm{C}$ as reported in other teleosts including Paralichthys olivaceus (Brooks \& Johnston, 1994), Rhamdia quellen (Rodrigues-Galdino et al., 2009) and for other species of fish (Gillooly et al., 2002). Moreover, the number of somites at hatching stage varied among species as observed in Gadus morhua (52 somites; Hall et al., 2004), Clupea harengus (62 somites; Hill \& Johnston, 1997), Salmo salar (60 somites; Gorodilov, 1996) and Danio rerio (32 somites; Kimmel et al., 1995).

Morrison et al. (2001) suggested that the variation in embryogenesis including asynchrony and malformation was related to the incubation temperature and the age of broodstocks.

In conclusion, this work presented new information and opened up possibilities for application in chromosome-set manipulation and biotechnology studies in the yellowtail tetra Astyanax altiparanae with potential application in aquaculture and academic research. Additionally, our data may also be applicable in other teleosts specially in neotropical characin species.

\section{Acknowledgements}

To Departamento de Morfologia e Fisiologia Animal da Faculdade de Ciências Agrárias e Veterinárias de Jaboticabal, São Paulo, Brazil (UNESP), for histological analysis. To CEPTA/ICMBio for providing the biological material, the Aquaculture Centre of UNESP (CAUNESP), the Laboratório de Microscopia Eletrônica of the Faculdade de Medicina de Ribeirão Preto (USP) for processing the SEM findings and Universidade de Zootecnia e Engenharia de Alimentos de Pirassununga/SP (USP) for support in data processing of fluorescence.

\section{Financial support}

The author expresses his gratitude to the Masters scholarship provided by $\mathrm{CNPq}$ (partial, Process 
131352/2012-1), FAPESP (process 2012/18961-4), the financial support provided by FAPESP (JP - FAPESP 2010/17429-1) and CNPq (Universal 471140/2012-0).

\section{References}

Amanze, D. \& Iyengar, A. (1990). The micropyle: a sperm guidance system in teleost fertilization. Development 109, 495-500.

Arai, K. (2001). Genetic improvement of aquaculture finfish species by chromosome manipulation techniques in Japan. Aquaculture 197, 205-28.

Brooks, S. \& Johnston, I.A. (1994). Temperature and somitogenesis in embryos of the plaice (Pleuronectes platessa). J. Fish Biol. 45, 699-702.

Camus, P. \& Koustikopoulos, C. (1984). Incubation experimentale et developpement embryonnaire de la daurade royale, Sparus aurata (L.), a differente temperatures. [Incubation and embryonic development of gilthead bream, Sparus aurata (L.), at a range of temperatures.] Aquaculture 42, 117-28.

Cruz-Casallas, P.E., Lombo-Rodriguez, D.A. \& VelascoSantamaria, Y.M. (2005). Milt quality and spermatozoa morphology of captive Brycon siebenthalae broodstock. Aquac. Res. 36, 682-6.

Dunham, R.A. (1990). Production and use of monosex or sterile fishes in aquaculture. Rev. Aquac. Sci. 2, 1-17.

Fribourgh, J.H., McClendon, D.E. \& Soloff, B.L. (1970). Ultrastructure of the goldfish, Carassius auratus spermatozoon. Copeia 2, 274-9.

Fujimoto, T., Kataoka, T., Sakao, S., Yamaha, E. \& Arai, K. (2006). Developmental stages and germ cell lineage of the loach (Misgurnus anguillicaudatus). Zool. Sc. 23, 977-89.

Gillooly, J.F., Charnov, E.L., West, G.B., Savage, V.M. \& Brown, J.H. (2002). Effects of size and temperature on developmental time. Nature 417, 70-3.

Ginsburg, A. S. (1968). Fertilization in Fishes and the Problem of Polyspermy. Izdatelnaya Nauka, Moskva, $354 \mathrm{pp}$.

Gjedrem, T. (2000). Genetic improvement of cold-water fish species. Aquac. Res. 31, 25-33.

Gorodilov, Y.N. (1996). Description of the early ontogeny of the Atlantic salmon, Salmo salar, with a novel system of interval (state) identification. Env. Biol. Fish. 47, 109-27.

Hall, T.E., Smith, P. \& Johnston, I.A. (2004). Stages of embryonic development in the Atlantic cod Gadus morhua. J. Morph. 259, 255-70.

Hart, N.H. (1990). Fertilization in teleost fishes: mechanisms of sperm-egg interactions. Int. Rev. Cytol. 121, 1-66.

Hill, J. \& Johnston, I. A. (1997). Temperature and neural development of the Atlantic herring (Clupea harengus L.). Comp. Biochem. Phys. 117, 457-62.

Itono, M., Okabayashi, N., Morishima, K., Fujimoto, T., Yoshikawa, H., Yamaha, E. \& Arai, K. (2007). Cytological mechanisms of gynogenesis and sperm incorporation in unreduced diploid eggs of the clonal loach, Misgurnus anguillicaudatus (Teleostei: Cobitidae). J. Exp. Zool. Part A Ecol. Genet. Physiol. 307, 35-50.

Iwamatsu, T. (2004). Stages of normal development in the medaka Oryzias latipes. Mech. Dev. 121, 605-18.
Jamieson, B.G.M. (1991). Fish Evolution and Systematics: Evidence from Spermatozoa. Cambridge, UK: Cambridge University Press.

Kimmel, C.B., Ballard, W.W., Kimmel, S.R., Ullmann, B. \& Schilling, T.F. (1995). Stages of embryonic development of the zebrafish. Dev. Dyn. 203, 253-310.

Komen, H. \& Thorgaard, G.H. (2007). Androgenesis, gynogenesis and the production of clones in fishes: a review. Aquaculture 269, 150-73.

Kudo, S. (1980). Sperm penetration and the formation of a fertilization cone in the common carp egg. Dev. Growth Differ. 22, 403-14.

Maria, A.N., Azevedo, H., Santos, J.P., Silva, C.A. \& Carneiro, P.C.F. (2010). Semen characterization and sperm structure of the Amazon tambaqui (Colossoma macropomum). J. Appl. Ichthyol. 26, 779-83.

Morrison, C.M., Miyake, T. \& Wright, J.R. (2001). Histological study of development of the embryo and early larva of Oreochromis niloticus (Pisces, Cichlidae). J. Morphol. 247, 172-96.

Ninhaus-Silveira, et al. (2006). Seminal analysis, cryogenic preservation, and fertility in matrinxa fish, Brycon cephalus. Braz. Arch. Biol. Technol. 49, 651-9.

Ohta, T., et al. (1993). Sperm morphology and distribution of intramenbranous particles in the sperm heads of selected freshwater teleosts. Tissue Cell 25, 725-35.

Peruzzi, S., Rudolfsen, G., Primicerio, R., Frantzen, M. \& Kaurić, G. (2009). Milt characteristics of diploid and triploid Atlantic cod (Gadus morhua L.). Aquac. Res. 40, $1160-9$.

Piferrer, F., Beaumontb, A., Falguièrec, J.C., Flajšhansd, M., Haffraye, P. \& Colombo, L. (2009). Polyploidy fish and shellfish: Production, biology and applications to aquaculture for improvement and genetic containment. Aquaculture 293, 125-56.

Rembold, M., Lahiri, K., Foulkes, N.S. \& Wittbrodt, J. (2006). Transgenesis in fish: efficient selection of transgenic fish by co-injection with a fluorescent reporter construct. Nat. Protoc. 1, 1133-9.

Rodrigues-Galdino, A.M., Maiolino, C.V., Forgati, M., Donatti, L., Mikos, J.D., Carneiro, P.C., \& Rios, F.S. (2009). Development of the neotropical catfish Rhamdia quellen incubated in different temperature regimes. Zygote 18, $131-44$.

Saito, T., Goto-Kazeto, R., Arai, K. \& Yamaha, E. (2008). Xenogenesis in teleost fish through generation of germ line chimeras by single primordial germ cell transplantation. Biol. Reprod. 78, 159-66.

Summers, R.G. \& Hylander, B.L. (1975). Species-specificity of acrosome reaction and primary gamete binding in echinoids. Exp. Cell Res. 96, 63-8.

Veloso-Júnior, V.C., Guimarães-Cruz, R.J., Barros, M.D.M., Barata, R.S.L. \& Santos, J.E. (2009). Reproduction of the lambari Astyanax scabripinnis in a small stream in southeastern Brazil. J. Appl. Ichthyol. 25, 314-20.

Veríssimo-Silveira, R., Gusmão-Pompiani, P., Vicentini, C. A. \& Quagio-Grassiotto, I. (2006). Spermiogenesis and spermatozoa ultrastructure in Salminus and Brycon, two primitive genera in Characidae (Teleostei: Ostariophysi: Characiformes). Acta Zool. 87, 305-13. 
Viveiros, A.T.M., et al. (2012). Spermatozoon ultrastructure and sperm cryopreservation of the Brazilian dry season spawner fish pirapitinga, Brycon nattereri. Aquacult Res. 43, 546-55.

Yasui, G. S., Arias-Rodrigues, L., Fujimoto, T. \& Arai, K. (2009). A sperm cryopreservation protocol for the loach Misgurnus anguillicaudatus and its applicability for other related species. Anim. Reprod. Sci. 116, 335-45.

Yasui, G.S., Fujimoto, T., Sakao, S., Yamaha, E. \& Arai, K. (2011). Production of loach (Misgurnus anguillicaudatus) germ-line chimera using transplantation of primordial germ cells isolated from cryopreserved blastomeres. J. Anim. Sci. 89, 2380-8.

Yasui, G. S., Fujimoto, T., Arias - Rodrigues, L., Takagi, Y. \& Arai, K. (2012). The effect of ions and cryoprotectants upon sperm motility and fertilization success in the loach Misgurnus anguillicaudatus. Aquaculture (Amsterdam) 344-9, 147-52.

Yasui, G.S., Senhorini, J.A., Shimoda, E., Pereira-Santos, M., Nakaghi, L.S.O., Fujimoto, T., Arias-Rodrigues, L. \& Silva, L.A. (2015). Improvement of gamete quality and its shortterm storage: an approach for biotechnology in laboratory fish. Animal 9, 464-70. 